\title{
Relationship between 24-hour blood pressure variability and mean carotid intimate index in essential hypertension
}

\author{
Relaţia dintre variabilitatea tensiunii arteriale pe 24 ore şi \\ indicele intimă medie carotidian în hipertensiunea arterială esenţială
}

\author{
Suzana Maria Guberna ${ }^{1,2}$, Nicoleta Avram², Cătălina Liliana Andrei ${ }^{1,2}$, Crina Sinescu1,2 \\ ${ }^{1}$ Universitatea de Medicină şi Farmacie „Carol Davila“, Bucureşti, România \\ ${ }^{2}$ Clinica de Cardiologie, Spitalul Clinic de Urgenţă „Bagdasar-Arseni“, Bucureşti, România
}

\begin{abstract}
Hypertension (HT) is recognized as a major risk factor for cardiovascular disease (CV) and mortality. The literature suggests that in order to achieve the highest degree of CV protection in hypertension, treatment should aim at decreasing the variability of blood pressure (BP) in 24 hours in addition to reducing the absolute levels of BP over 24 hours.

Aim. The study purpose was to analyze the relationship between changes in BP values produced during the day, determined by ambulatory blood pressure measurement (ABPM) and target organs lesion expressed by the intima-media thickness of the carotid artery in a group of patients newly diagnosed with HT based on the hypothesis of correlation between systolic (s) and diastolic (d) BP variability and target organs lesion. Material and method. We enrolled 60 patients recently diagnosed with HT and not treated before enrollment. All subjects were monitored by ambulatory blood pressure monitoring and the degree of target organ lesion was assessed by carotidian intima-media thickness.

BP variability was calculated as standard deviation (SD) and average real variability (ARV) of systolic and diastolic BP. The subjects were subsequently divided into quartiles of BP variability. The correlations between carotidian intima-media thickness and BP variability parameters, demographic parameters and hypertensive load were analised using Pearson coefficient.

Results. The mean age of patients was $60.56+/-6.76$ years, $43.33 \%$ were male, $66.66 \%$ had family history of HT. The mean body mass index (BMI) was $27.9+/-4.47 \mathrm{~kg} / \mathrm{m}^{2}$. The analise of the quartiles of the BP variability parameters showed that the carotidian intima-media thickness value is not influenced by the average BP value and that the S BP variability calculated by DS is statistically significantly correlated with the carotidian intima-media thickness value. Using Pearson coefficient, we observed that the carotidian intimamedia thickness value is significantly correlated with the body mass index and with the variability of $s$ BP expressed by both SD and AVR and with the variability of d BP expressed by SD. It was also observed that the hypertensive load is not correlated with the carotidian intima-media thickness value.

The results of the present study showed that the variability of $\mathrm{SP} / 24 \mathrm{~h}$ is correlated with carotidian intimamedia thickness independent of mean BP values, in a cohort of recently diagnosed and untreated hypertensive subjects.
\end{abstract}

Keywords: carotidian intima-media thickness, blood pressure variability

\section{REZUMAT}

Hipertensiunea arterială (HTA) este recunoscută ca un factor de risc major, tradiţional pentru afecţiunile cardiovasculare (CV) şi mortalitate. Literatura prezentă sugerează faptul că, pentru a atinge cel mai înalt grad de protecţie CV la pacienţii hipertensivi, tratamentul ar trebui să vizeze scăderea variabilităţii TA/24 de ore în plus faţă de reducerea nivelurilor absolute ale TA/24 de ore.

Obiectiv. Studiul îşi propune analiza relaţiei dintre schimbările în valorile TA produse în cursul unei zile, determinate prin monitorizare ambulatorie de tensiune arterială (MATA), şi afectarea organelor ţintă, exprimată prin indicele intimă medie carotidian în cazul unui grup de pacienţi nou diagnosticaţi cu HTA pornind de la ipoteza corelării variabilităţii TA sistolice (TAs) şi diastolice (TAd) cu afectarea de organe ţintă. 


\begin{abstract}
Material şi metodă. Au fost înrolaţi 60 de pacienţi recent diagnosticaţi cu HTA şi netrataţi. Toţi subiecţii au fost monitorizaţi prin monitorizare ambulatorie a tensiunii arteriale, gradul de afectare a organelor ţintă în cazul acestui studiu au fost evaluat prin indicele intimă medie carotidian (IMT). Varabilitatea TA a fost calculată ca deviaţie standard (DS) şi variabilitate reală medie (AVR) a TAs şi TAd. Subiecţii au fost divizaţi ulterior în quartile ale variabilităţii TA. Folosind coeficientul Pearson, s-au analizat corelaţiile dintre indicele intimă medie carotidian şi parametrii variabilităţii TA, parametrii demografici şi încărcătura hipertensivă.

Rezultate. Vârsta medie a pacienţilor a fost de $60,56+/-6,76$ ani, 43,33\% au fost bărbaţi, $66,66 \%$ au avut antecedente heredocolaterale (AHC) de HTA. Indicele mediu al masei corporale (BMI) a fost de 27,9 +/- 4,47 $\mathrm{kg} / \mathrm{m}^{2} \mathrm{sc}$.

Analizând quartilele parametrilor variabilităţii TA, se constată că: valoarea IMT nu este influenţata de valoarea TA medii şi că variabilitatea TAs calculată prin DS este corelată semnificativ statistic cu valoarea IMT carotidian. Folosind coeficientul Pearson, se observă că valoarea IMT este semnificativ corelată cu BMI şi cu variabilitatea TAs exprimată atât prin DS, cât şi prin AVR şi cu variabilitatea TAd exprimată prin DS. De asemenea, se observă că încărcătura hipertensivă nu este corelată cu valoarea IMT.

Concluzie. Rezultatele studiului prezent arată că variabilitatea TAs/24 h se corelează cu IMT carotidian independent de valorile medii ale TA, într-o cohortă de subiecţi hipertensivi diagnosticaţi recent şi netrataţi.
\end{abstract}

Cuvinte cheie: indicele intimă medie carotidian, variabilitatea tensiunii arteriale

\section{INTRODUCERE}

Hipertensiunea arterială (HTA) este recunoscută ca un factor de risc major tradiţional pentru afecţiunile cardiovasculare $(\mathrm{CV})$ şi mortalitate şi are o contribuţie majoră la povara bolii la nivel mondial. Aceasta determină un risc crescut de evenimente cardiovasculare. Prima etapă în afectarea CV este apariţia aşa-numitor leziuni subclinice de organ: disfuncţie renală subclinică (microalbuminurie), hipertrofie ventriculară stângă (HVS), creşterea grosimii intimă-medie la nivel carotidian, rigiditate arterială măsurată prin velocitatea undei de puls (PWV).

Dovezile din studii observaţionale au indicat că riscul de morbiditate şi mortalitate $\mathrm{CV}$ are o relaţie puternică şi continuă cu nivelurile TA medii şi că scăderea nivelurilor TA conferă protecţie CV semnificativă, indiferent de clasa de medicament utilizată. Nivelurile TA măsurate prin monitorizarea ambulatorie a TA (MATA) sau prin autodeterminare la domiciliu s-au dovedit a fi chiar mai buni predictori pentru prognostic, comparativ cu TA măsurată la cabinet, şi pot permite, de asemenea, identificarea HTA mascate şi a HTA de halat alb.

Datele rezultate din analiza retrospectivă a studiilor clinice indică faptul că diminuarea variabilităţii TA ar ajuta la scăderea ratei evenimentelor CV majore la pacienţii hipertensivi.

Literatura prezentă sugerează faptul că, pentru a atinge cel mai înalt grad de protecţie CV la pacienţii hipertensivi, tratamentul ar trebui să vizeze scăderea variabilităţii TA/24 de ore în plus faţă de reducerea nivelurilor absolute ale $\mathrm{TA} / 24$ de ore. Studiul de faţă îşi propune analiza relaţiei dintre schimbările în valorile TA produse în cursul unei zile, determinate prin MATA, şi afectarea organelor ţintă, exprimată prin indicele intimă medie carotidian (IMT) în cazul unui grup de pacienţi nou diagnosticaţi cu HTA, pornind de la ipoteza corelării variabilităţii TA sistolice (s) şi diastolice (d) cu afectarea de organe ţintă. Un obiectiv secundar al studiului este reprezentat de determinarea celei mai adecvate modalităţi statistice pentru exprimarea variaţiilor tensionale în raport cu modificarea indicelui intimă medie carotidian.

\section{MATERIAL ŞI METODE}

\section{Populația de studiu}

Studiul a înrolat 60 de pacienţi recent diagnosticaţi cu HTA şi netrataţi până la efectuarea lui. Pacienţii s-au adresat clinicii noastre din cauza unui diagnostic recent de HTA, stabilit prin măsurarea clinică a TA. Pacienţii nu aveau istoric de HTA, având anamnestic cel puţin o măsurătoare a TA înaintea celei incriminate, cu valoare normală în ultimele 12 luni. Am presupus că depistarea HTA în cazul grupului de studiu s-a făcut la începutul evoluţiei naturale a bolii.

Criteriile de excludere au fost reprezentate de alte afecţiuni implicate în leziunea subclinică de organe ţintă (DZ de tip 1 sau 2 cunoscut sau diagnosticat la momentul screening-ului, disfuncţia renală - creatinina serică $>2 \mathrm{mg} / \mathrm{dl}$, hipertensiunea secundară cunoscută sau suspectată, inclusiv hipertensiunea arterială secundară consumului de medicamente), insuficienţa cardiacă avansată, prezenţa leziunilor clinice de organe ţintă (boală coronariană documentată sau angină pectorală, accident vascular cerebral sau atac ischemic tranzitor în antecedente; boală arterială periferică), tratament medicamentos cu antihipertensive timp de peste 1 lună, fibrilaţia atrială permanentă ca urmare a artefactării măsurării TA cauzate de ritmul car- 
diac neregulat, pacienţii cu cooperare limitată sau capacitate legală limitată, bolile noncardiovasculare grave, condiţii care afectează speranţa de viaţă, boala severă a valvelor cardiace.

Fiecare pacient a semnat un consimţământ informat. Toate procedurile care privesc subiecţii umani au fost efectuate în conformitate cu liniile directoare stabilite în Declaraţia de la Helsinki (octombrie 2008).

Evaluarea pacienţilor a cuprins anamneza, datele demografice, factorii de risc şi stilul de viaţă, antecedente heredocolaterale (AHC) de HTA, examinarea fizică, tratamentele cronice curente. Toţi subiecţii au fost monitorizaţi prin monitorizare ambulatorie a tensiunii arteriale.

Gradul de afectare a organelor ţintă în cazul acestui studiu a fost evaluat prin IMT carotidian.

\section{Monitorizarea TA în ambulator şi evaluarea Vr TA}

Toţi subiecţii au fost supuşi la MATA nonivaziv cu durata de 24 de ore folosind un dispozitiv oscilometric validat (Meditech-Meditech Ltd, Budapesta, Ungaria). S-au folosit manşete de dimensiuni potrivite cu circumferinţa braţului. Manşeta a fost pusă pe braţul nondominant la nivelul inimii.

Monitorizarea TA a fost făcută în timp ce subiecții efectuau activităţi zilnice de rutină (subiecţii au fost monitorizaţi prin MATA în zilele de lucru). Citirile TA au fost realizate la intervale de 15 minute în timpul zilei şi la intervale de 30 de minute în timpul nopţii.

Subiecţii au fost instruiţi să menţină activitatea normală, cu excepţia momentului în care se fac măsurătorile. Când se efectuează măsurătoarea, am recomandat ca braţul subiectului să fie întins pe lângă trunchi şi nemişcat.

Variabilitatea tensiunii arteriale a fost calculată ca deviaţie standard (DS) şi variabilitate reală medie (AVR) pentru TA s şi d.

De asemenea, a fost înregistrată încărcătura hipertensivă, care este definită ca proporţia valorilor TA pe parcursul a 24 de ore care depăşesc valoarea ţintă din timpul zilei şi din timpul somnului (> 140/90 mm Hg în timpul zilei şi > 120/80 mm Hg în timpul orelor de somn). Încărcătura hipertensivă în studiul nostru a fost definită ca procentul citirilor TA sistolice $>135 \mathrm{~mm} \mathrm{Hg}$, respectiv $>85$ $\mathrm{mm} \mathrm{Hg}$.

\section{Determinarea indicelui intimă medie carotidian (IMT)}

Măsurarea IMT reprezintă o metodă de a detecta modificări subclinice în structura peretelui vas- cular, modificări care preced şi prezic evenimentele CV. Ecografia carotidiană este o metodă imagistică uşor de realizat, neinvazivă, sigură, reproductibilă, sensibilă, relativ ieftină şi disponibilă pe scară largă pentru detectarea stadiilor incipiente ale aterosclerozei şi, în prezent, este considerată una dintre cele mai bune metode de evaluare a structurii peretelui arterial.

IMT este definit ca un model dublu-liniar vizualizat prin ecografie 2D pe ambii pereţi ai arterei carotide comune, secţiune longitudinală. Se descriu două linii paralele: interfaţa lumen-intimă şi interfaţa medie-adventice.

Pentru a evita diferenţe de măsurare, au fost elaborate standarde pentru măsurarea IMT (1).

Ultrasonografia carotidiană a fost realizată cu un ecograf Aloka Prosound $\alpha 7$ IPF -1701B echipat cu un transductor liniar de $10 \mathrm{MHz}$, cu subiecţii în clinostatism, cu gâtul în uşoară hiperextensie. Măsurătorile IMT la nivelul arterei carotide comune au fost efectuate în conformitate cu protocolul recomandat de Societatea Europeană de Cardiologie. S-a obţinut o imagine optimă longitudinală bidimensională. Această procedură a fost repetată de 3 ori pentru fiecare perete distal, stâng şi drept, iar apoi a fost făcută media celor 6 valori obţinute. Măsurătorile IMT au fost efectuate $1 \mathrm{la} 1 \mathrm{~cm}$ proximal de bifurcaţia arterei carotide comune.

\section{Metode statistice}

Variabilele continue au fost exprimate ca medie +/- DS. Variabilele discrete au fost exprimate ca procente.

Valorile de la monitorizarea MATA au fost analizate şi, pentru fiecare subiect, a fost înregistrată TAs medie/24 h, TAd medie/24. S-au calculat DS şi ARV pentru fiecare pacient pentru TAs, TAd. De asemenea, s-a înregistrat încărcătura hipertensivă pentru TAs şi TAd, sub formă de procente, conform criteriilor descrise mai sus.

Subiecţii au fost divizaţi ulterior în quartile ale variabilităţii TAs, TAd pe 24 de ore. Pentru a testa diferenţele dintre quartile, am folosit testul ANOVA pentru variabilele continue, iar pentru variabilele discrete am folosit testul Chi pătrat.

Folosind corelaţia Pearson, s-a analizat corelaţia dintre fiecare parametru derivat din MATA cu indicele intimă medie carotidian.

Limita pentru a exclude ipoteza nulă a fost considerată $\mathrm{P}<0,05$.

Analiza statistică a fost efectuată cu ajutorul Microsoft Excel. 


\section{REZULTATE}

\section{Parametrii demografici}

Vârsta medie a pacienților a fost de 60,56 +/6,76 (min 50 ani, $\max 75$ ani). Studiul a înrolat 26 pacienți de sex masculin (43,33\%). 40 dintre pacienţii înrolaţi (66,66\%) au avut AHC de HT. Indicele mediu al masei corporale (BMI) a fost de 27,9 $+/-4,47 \mathrm{~kg} / \mathrm{m}^{2} \mathrm{sc}$, cu un BMI maxim în lotul de studiu de $35 \mathrm{~kg} / \mathrm{m}^{2}$ sc şi un BMI minim de $19 \mathrm{~kg} / \mathrm{m}^{2}$ sc.

\section{Parametrii MATA}

Media TAs a fost $145,09+/-8,80 \mathrm{mmHg}$ (min $120,78 \mathrm{mmHg}$, max $161,26 \mathrm{mmHg}$ ), media TAd a fost $82,78+/-6,50 \mathrm{mmHg}(\min 69,57 \mathrm{mmHg}$, max $98,48 \mathrm{mmHg}$ ).

\section{Parametrii de variabilitate ai TA}

Deviaţia standard (DS)

DS a TAs a fost $16,33+/-3,22 \mathrm{mmHg}$ (min $10,48 \mathrm{mmHg}$, max. $25,46 \mathrm{mmHg}$ ).

DS a TAd a fost 9,59+/- 2,21 mmHg (min. 5,52 $\mathrm{mmHg}$, max. 16,84 $\mathrm{mmHg}$ ).

Variabilitatea reală medie (ARV)

ARV TA s a fost $10,06+/-4,68 \mathrm{mmHg}$ (min. 2,47 mmHg, max. 16,56 $\mathrm{mmHg}$ ).

ARV TA d a fost $6,11+/-2,52 \mathrm{mmHg}$ (min. $1,54 \mathrm{mmHg}$, max. 9,79 mmHg).

Încărcătura hipertensivă

Încărcătura sistolică a fost $67,4+/-20,86 \%$ (min. 14\%, max. 98\%).

Încărcătura diastolică a fost $42,69+/-23,03 \%$ (min. $1,3 \%$, max. 98\%).

\section{Afectarea de organ țintă}

IMT a fost $0,88+/-0,07 \mathrm{~mm}$ (min. 0,69 mm, max. 1,01 mm).

\section{Quartilele variabilității tensiunii arteriale}

Aşa cum am menţionat mai sus, pacienţii au fost divizaţi în quartile în funcţie de parametrii variabilităţii TA şi în funcţie de TA medie sistolică şi diastolică. Prin testul ANOVA, am studiat diferenţele între quartile.

TABEL 1. Quartilele TAs

\begin{tabular}{|l|c|c|c|c|c|}
\hline Variabila & $\begin{array}{c}\text { Quartila } \\
\mathbf{1}\end{array}$ & $\begin{array}{c}\text { Quartila } \\
\mathbf{2}\end{array}$ & $\begin{array}{c}\text { Quartila } \\
\mathbf{3}\end{array}$ & $\begin{array}{c}\text { Quartila } \\
\mathbf{4}\end{array}$ & $\mathbf{p}$ \\
\hline Vârsta & $60,33+/$ & $61,46+/$ & $61,53+/$ & $58,93+/$ & 0,70 \\
(ani) & $-7,25$ & $-6,71$ & $-6,42$ & $-7,00$ & 0,73 \\
\hline Sex (M)\% & 60 & 46,66 & 33,33 & 33,33 & 0,39 \\
\hline AHC (\%) & 66,66 & 73,33 & 60 & 66,66 & 0,84 \\
\hline $\mathrm{BMI}$ & $28,46+/$ & $28,86+/$ & $27,06+/$ & $27,2+/$ & 0,61 \\
(kg/m²) & $-5,62$ & $-4,05$ & $-4,19$ & $-4,00$ & 0,0 \\
\hline \multirow{2}{*}{ IMT (mm) } & $0,86+/$ & $0,88+/$ & $0,91+/$ & $0,85+/$ & 0,24 \\
& $-0,08$ & $-0,08$ & $-0,05$ & $-0,08$ & 0 \\
\hline
\end{tabular}

TABEL 2. Quartilele TAd

\begin{tabular}{|c|c|c|c|c|c|}
\hline Variabila & $\begin{array}{c}\text { Quartila } \\
1 \\
\end{array}$ & $\begin{array}{c}\text { Quartila } \\
2\end{array}$ & $\begin{array}{c}\text { Quartila } \\
\mathbf{3}\end{array}$ & $\begin{array}{c}\text { Quartila } \\
4 \\
\end{array}$ & p \\
\hline $\begin{array}{l}\text { Vârsta } \\
\text { (ani) }\end{array}$ & $\begin{array}{c}61,46+/ \\
-8,06\end{array}$ & $\begin{array}{c}59,66+/ \\
-5.72 \\
\end{array}$ & $\begin{array}{c}61,93+/ \\
-6,31 \\
\end{array}$ & $\begin{array}{c}59,2+/ \\
-7,02 \\
\end{array}$ & 0,63 \\
\hline Sex (M)\% & 60 & 26,66 & 40 & 46,66 & 0,31 \\
\hline $\mathrm{AHC}(\%)$ & 53,33 & 73,33 & 73,33 & 66,66 & 0,61 \\
\hline $\begin{array}{l}\text { BMI } \\
\left(\mathrm{kg} / \mathrm{m}^{2}\right)\end{array}$ & $\begin{array}{c}28,26+/ \\
-4,52 \\
\end{array}$ & $\begin{array}{c}26,53+/ \\
-5,31 \\
\end{array}$ & $\begin{array}{c}29,33+/ \\
-3,22 \\
\end{array}$ & $\begin{array}{c}27,46+/ \\
-4,54\end{array}$ & 0,37 \\
\hline $\mathrm{IMT}(\mathrm{mm})$ & $\begin{array}{c}0,88+/ \\
-0,05\end{array}$ & $\begin{array}{c}0,87+/ \\
-0,07\end{array}$ & $\begin{array}{c}0,90+1 \\
-0,08\end{array}$ & $\begin{array}{c}0,86+/ \\
-0,08\end{array}$ & 0,53 \\
\hline
\end{tabular}

\section{Deviații standard}

TABEL 3. Quartilele DS pentru TAS

\begin{tabular}{|c|c|c|c|c|c|}
\hline Variabila & $\begin{array}{c}\text { Quartila } \\
1\end{array}$ & $\begin{array}{c}\text { Quartila } \\
2\end{array}$ & $\begin{array}{c}\text { Quartila } \\
3\end{array}$ & $\begin{array}{c}\text { Quartila } \\
4\end{array}$ & $\mathbf{P}$ \\
\hline $\begin{array}{l}\text { Vârsta } \\
\text { (ani) }\end{array}$ & $\begin{array}{c}58,8+/ \\
-6,13\end{array}$ & $\begin{array}{c}59,2+/ \\
-5,49\end{array}$ & $\begin{array}{c}64,8+/ \\
-6,17\end{array}$ & $\begin{array}{c}59,46+/ \\
7,81\end{array}$ & $<0.05$ \\
\hline Sex (M)\% & 33,33 & 26,66 & 60 & 53,33 & 0,20 \\
\hline $\mathrm{AHC}(\%)$ & 46,66 & 80 & 73,33 & 66 & 0,24 \\
\hline $\begin{array}{l}\text { BMI } \\
\left(\mathrm{kg} / \mathrm{m}^{2}\right)\end{array}$ & $\begin{array}{c}24,93+/ \\
-4,30 \\
\end{array}$ & $\begin{array}{c}28,73+/ \\
-4,0 \\
\end{array}$ & $\begin{array}{c}28,73+/ \\
4,28 \\
\end{array}$ & $\begin{array}{c}29,2+/ \\
-4,27 \\
\end{array}$ & $<0,05$ \\
\hline IMT (mm) & $\begin{array}{c}0,94+/ \\
-0,03\end{array}$ & $\begin{array}{c}0,91+/ \\
-0,05\end{array}$ & $\begin{array}{c}0,83+/ \\
-0,07\end{array}$ & $\begin{array}{c}0,82+/ \\
-0,06\end{array}$ & $<0,05$ \\
\hline
\end{tabular}

TABEL 4. Quartilele DS pentru TAd

\begin{tabular}{|l|c|c|c|c|c|}
\hline Variabila & $\begin{array}{c}\text { Quartila } \\
\mathbf{1}\end{array}$ & $\begin{array}{c}\text { Quartila } \\
\mathbf{2}\end{array}$ & $\begin{array}{c}\text { Quartila } \\
\mathbf{3}\end{array}$ & $\begin{array}{c}\text { Quartila } \\
\mathbf{4}\end{array}$ & $\mathbf{P}$ \\
\hline Vârsta & $60,66+/$ & $61,93+/$ & $61,66+/$ & $58+/$ & 0 \\
(ani) & -6.10 & $-6,63$ & $-7,10$ & $-7,12$ & 0,49 \\
\hline Sex $(\mathrm{M}) \%$ & 53,33 & 40 & 26,66 & 53,33 & 0,39 \\
\hline $\mathrm{AHC}(\%)$ & 46,66 & 86,66 & 66,66 & 66,66 & 0,14 \\
\hline $\mathrm{BMI}$ & $26,46+/$ & $27,93+/$ & $28,33+/$ & $28,86+/$ & 0,5 \\
(kg/m²) & $-4,32$ & $-4,74$ & $-3,57$ & $-5,19$ & 0,5 \\
\hline IMT $(\mathrm{mm})$ & $0,91+/$ & $\begin{array}{c}0,89+/ \\
-0,06\end{array}$ & $\begin{array}{c}0,87+/ \\
-0,07\end{array}$ & $\begin{array}{c}0,84+/ \\
-0,07\end{array}$ & 0,05 \\
\hline
\end{tabular}

\section{Variabilitatea reală medie}

TABEL 5. Quartilele ARV pentru TAs

\begin{tabular}{|l|c|c|c|c|c|}
\hline Variabila & $\begin{array}{c}\text { Quartila } \\
\mathbf{1}\end{array}$ & $\begin{array}{c}\text { Quartila } \\
\mathbf{2}\end{array}$ & $\begin{array}{c}\text { Quartila } \\
\mathbf{3}\end{array}$ & $\begin{array}{c}\text { Quartila } \\
\mathbf{4}\end{array}$ & $\mathbf{P}$ \\
\hline $\begin{array}{l}\text { Vârsta } \\
\text { (ani) }\end{array}$ & $\begin{array}{c}62,33+/ \\
-5,8\end{array}$ & $\begin{array}{c}62,33+/ \\
-5,8\end{array}$ & $\begin{array}{c}58,53+/ \\
-7,4\end{array}$ & $\begin{array}{c}60,27+/ \\
-7,7\end{array}$ & 0,48 \\
\hline Sex (M)\% & 60 & 46,66 & 33,33 & $33 ., 3$ & 0,39 \\
\hline AHC (\%) & 73,33 & 80 & 46,66 & 66,66 & 0,24 \\
\hline BMI & $27,33+/$ & $28,00+/$ & $28,73+/$ & $27,53+/$ & 0,84 \\
(kg/m $\left./ \mathrm{m}^{2}\right)$ & $-5,41$ & $-4,46$ & $-3,53$ & $-4,64$ & 0,8 \\
\hline IMT (mm) & $\begin{array}{c}0,92+/ \\
-0,07\end{array}$ & $\begin{array}{c}0,89+/ \\
-0,09\end{array}$ & $\begin{array}{c}0,87+/ \\
-0,06\end{array}$ & $\begin{array}{c}0,85+/ \\
-0,07\end{array}$ & 0,06 \\
\hline
\end{tabular}

TABEL 6. Quartilele ARV pentru TAd

\begin{tabular}{|l|c|c|c|c|c|}
\hline Variabila & $\begin{array}{c}\text { Quartila } \\
\mathbf{1}\end{array}$ & $\begin{array}{c}\text { Quartila } \\
\mathbf{2}\end{array}$ & $\begin{array}{c}\text { Quartila } \\
\mathbf{3}\end{array}$ & $\begin{array}{c}\text { Quartila } \\
\mathbf{4}\end{array}$ & $\mathbf{P}$ \\
\hline Vârsta (ani) & $\begin{array}{c}62,93+/ \\
-5,90\end{array}$ & $\begin{array}{c}60,20+/ \\
-7,20\end{array}$ & $\begin{array}{c}61,00+/ \\
-6,88\end{array}$ & $\begin{array}{c}58,13+/ \\
-6,80\end{array}$ & 0,28 \\
\hline Sex (M)\% & 73,33 & 26,66 & 60 & 13,33 & 0,002 \\
\hline AHC (\%) & 73,33 & 66,66 & 60 & 66,66 & 0,90 \\
\hline BMI & $28,33+$ & $27,73+/$ & $28,40+/$ & $27,13+/$ & 0,86 \\
(kg/m $\left.{ }^{2}\right)$ & $-4,61$ & $-5,24$ & $-3,85$ & $-4,44$ & $0, /$ \\
\hline \multirow{2}{*}{ IMT (mm) } & $\begin{array}{c}0,89+/ \\
-0,09\end{array}$ & $\begin{array}{c}0,89+/ \\
-0,07\end{array}$ & $\begin{array}{c}0,87+/ \\
-0,08\end{array}$ & $\begin{array}{c}0,88+/ \\
-0,06\end{array}$ & 0,85 \\
\hline
\end{tabular}


Din tabelele de mai sus, se observă că variabilitatea TA sistolice, exprimată prin DS, este corelată semnificativ statistic cu valoarea IMT carotidian. Valoarea IMT nu este diferită semnificativ statistic între quartilele variabilităţii TA, măsurată prin AVR. De asemenea, se observă că variabilitatea TA diastolice nu influenţează valoarea IMT.

Într-o etapă ulterioară, am studiat, cu ajutorul coeficientului Pearson, corelaţiile între parametrii demografici şi ai variabilităţii TA, obţinuţi prin MATA cu IMT.

TABEL 7. Corelația între parametrii demografici şi valoarea IMT

\begin{tabular}{|c|c|c|}
\hline & & CP \\
\hline Vârsta & & $-0,02(\mathrm{P}=0,87)$ \\
\hline & IMT & \\
\hline BMI & & $-0,29(P<0,05)$ \\
\hline
\end{tabular}

Se observă că valoarea BMI se corelează semnificativ statistic cu valoarea IMT.

TABEL 8. Corelația între parametrii obținuți prin monitorizarea ambulatorie a TA şi valoarea IMT

\begin{tabular}{|c|c|c|c|c|c|c|c|c|}
\hline \multicolumn{3}{|c|}{ DS } & \multicolumn{3}{c|}{ Tensiuni medii } & \multicolumn{3}{c|}{ ARV } \\
\hline & & CP & & & CP & & & CP \\
\hline DS s & & & S & & & ARV S & & \\
\hline DS d & IMT & $\begin{array}{c}0,63 \\
(P<0,05)\end{array}$ & IMT & $\begin{array}{c}0,02 \\
(P=0,87)\end{array}$ & & IMT & $\begin{array}{c}0,33 \\
(P<0,05)\end{array}$ \\
\hline & IMT & $\begin{array}{c}0,28 \\
(P<0,05)\end{array}$ & IMT & $\begin{array}{c}0,08 \\
(P=0,5)\end{array}$ & & IMT & $\begin{array}{c}0,11 \\
(P=0,4)\end{array}$ \\
\hline
\end{tabular}

TABEL 9. Corelația între încărcătura hipertensivă şi valoarea IMT

\begin{tabular}{|c|c|c|}
\hline \multicolumn{3}{|c|}{ Încărcătura hipertensivă } \\
\hline & & CP \\
\hline S & & \\
\hline & IMT & $-0,09(\mathrm{P}=0,49)$ \\
\hline D & & \\
\hline & IMT & $0,08(P=0,5)$ \\
\hline
\end{tabular}

Se observă că valoarea IMT este semnificativ corelată cu indicele de masă corporală şi cu variabilitatea TAs, exprimată atât prin DS, cât şi prin AVR. Încărcătura hipertensivă nu este corelată cu valoarea IMT.

\section{DISCUȚII}

Literatura prezentă nu a ajuns încă la un consens în ceea ce priveşte impactul variabilităţii TA. Poate fi considerată aceasta un factor de risc pentru ateroscleroză accelerată sau evenimente cardiovasculare indiferent de nivelul mediu al TA?

Impactul variabilităţii TA asupra riscului $\mathrm{CV}$ a fost explorat în studii incluzând subiecţi hipertensivi trataţi sau netrataţi $(2,3)$ sau din populaţia generală (4). Unele studii nu au găsit asociere independentă între variabilitatea TA şi risc (4), în timp ce asocierea a fost observată în alte studii (5).

Unele studii au constatat că leziunea organelor ţintă în HTA nu a fost determinată doar de nivelul creşterilor tensionale, ci şi de magnitudinea variabilităţii TA care a avut loc în perioada de 24 de ore $(4,6)$. În plus, Kikuya şi colab. au arătat că variabilitatea TA a fost un predictor independent al mortalităţii CV în populaţia generală (6). Cu toate acestea, Hansen şi colab. au concluzionat că variabilitatea TA rămâne un predictor evaziv al prognosticului $\mathrm{CV}$, deoarece a fost puternic asociat cu nivelul TA medii (7). Sunt necesare încă mai multe dovezi pentru a evalua dacă variabilitatea TA este un predictor independent al aterosclerozei sau al evenimentelor CV.

Studii anterioare au constatat că variabilitatea TA pe termen scurt ( 24 ore) a avut unele efecte asupra alterării arterelor carotide (creşterea IMT şi ateroscleroză) şi asupra formării plăcii $(2,8,9)$.

Variabilitatea TA în decurs de 24 de ore poate fi evaluat prin indici diferiţi. Nu este clar dacă efectele induse de diferiţi indici ai variabilităţii TA sunt egale. În prezentul nostru studiu, am constatat că fluctuaţiile TA în 24 de ore, exprimate ca DS, au fost semnificativ asociate cu creşterea IMT carotidian.

Constatarea noastră confirmă rezultatele raportate ale lui García-García şi colab. (10), care au examinat relaţia variabilităţii TA pe 24 de ore cu structura şi funcţia vasculară folosind DS şi coeficientul de variaţie. În studiul lor, DS şi coeficientul de variaţie al TAs diurne au fost corelate semnificativ $\mathrm{cu}$ valoarea IMT. Nu au fost decelate corelaţii semnificative între variabilitatea TAd şi IMT. Concluzii similare au fost obţinute şi din studiul European Lacidipine Study on Atherosclerosis (ELSA) în ceea ce priveşte relaţia dintre variabilitatea TAs şi IMT (11). Studiul ELSA a indicat faptul că IMT s-a asociat în mod pozitiv cu TA medie pe 24 de ore, diurnă şi nocturnă, dar şi cu DS a TAs pe 24 de ore.

O contribuţie importantă a studiului nostru este compararea efectelor asupra structurii arterei carotide pentru diferiţi indici ai variabilităţii TA. Aceste constatări suş̧in opinia că importanţa prognostică a variabilităţii TA va fi afectată de indicii de variabilitate folosiţi (12). Într-un studiu efectuat pe o populaţie din America Latină (13), Mena şi colab. au constatat că indicele DS utilizat în mod obişnuit poate fi mai sensibil la frecvenţa de eşantionare scăzută a dispozitivelor MATA, iar indicele ARV este o reprezentare mai fiabilă pentru semnificaţia prognostică a variabilităţii TA. Concluzii similare au fost arătate în studiile lui StolarzSkrzypek şi colab. (14) şi Hansen şi colab. (15). În 
prezentul studiu, AVR nu este superioară indicelui tradiţional, DS, pentru prezicerea afectării arterelor carotide. Relaţia pozitivă clară între variabilitatea TA şi IMT în studiul nostru, faţă de rapoartele care nu gasesc această asociaţie, este, probabil, dată de absenţa tratamentului - criteriu de includere în acest studiu.

Se remarcă o serie de limitări ale studiului prezent, cum ar fi numărul relativ mic de pacienţi, ceea ce face dificilă sau chiar imposibilă decelarea de anomalii ale organelor ţintă de mai mare finețe; caracterul transversal al acestuia, care permite decelarea unor corelaţii între variabilitatea TA şi afectarea vasculară, fără a se putea stabili însă o relaţie de tip cauză-efect. Studiul a fost efectuat pe pacienţi hipertensivi, recent diagnosticaţi, fără comorbidităţi semnificative şi fără boală CV documentată şi, astfel, rezultatele nu pot fi extrapolate la pacienţii hipertensivi vechi şi/sau trataţi şi nici la pacienţii cu boală CV documentată.

\section{CONCLUZII}

Obiectivul principal al studiul de față a fost demonstrarea asocierii unei afectări mai importante la nivel vascular, afectare măsurată prin IMT la pacienţii cu variabilitate crescută a TA, precum şi determinarea celei mai adecvate modalităţi statistice de cuantificare a variabilităţii TA pentru a prezice existenţa afectării organelor ţintă exprimată ca IMT.

Rezultatele studiului nostru, care arată că variabilitatea TAs/24 h se corelează cu IMT carotidian

\section{BIBLIOGRAFIE}

1. Simova I. Intima-media thickness: appropriate evaluation and proper measurement. E-Journal of Cardiology Practice. 2015;13:21.

2. Sander D, Kukla C, Klingelhofer J et al. Relationship between circadian blood pressure patterns and progression of early carotid atherosclerosis: a 3-year follow-up study. Circulation 2000; 102:1536-1541.

3. Parati G, Pomidossi G, Albini F et al. Relationship of 24-hour blood pressure mean and variability to severity of target organ damage in hypertension. J Hypertens. 1987;5:93-98.

4. Sega R, Corrao G, Bombelli M et al. Blood pressure variability and organ damage in a general population: results from the PAMELA study (Pressioni Arteriose Monitorate E Loro Associazioni). Hypertension 2002;39:710-714.

5. Chobanian AV, Bakris GL, Black HR et al. Seventh report of the Joint National Committee on Prevention, Detection, Evaluation, and Treatment of High Blood Pressure. Hypertension 2003;42:1206-52.

6. Kikuya M, Hozawa A, Ohokubo T et al. Prognostic significance of blood pressure and heart rate variabilities: the Ohasama Study. Hypertension 2000;36:901-906.

7. Hansen TW, Li Y, Staessen JA, Blood pressure variability remains an elusive predictor of cardiovascular outcome. The American Journal of Hypertension 2009;22:3-4.

8. Schillaci G, Bilo G, Pucci G et al. Relationship between short-term blood pressure variability and large-artery stiffness in human hypertension findings from 2 large databases. Hypertension 2012; 60:369-377. independent de valorile medii ale TA, într-o cohortă de subiecţi hipertensivi diagnosticaţi recent şi netrataţi, ajută la extinderea cunoştinţelor anterioare cu privire la relaţia variabilităţii TA cu lezarea organului ţintă, indicând faptul că lezarea vasculară şi miocardică prin HTA începe precoce, atât cu o componentă care poate fi atribuită nivelului mediu de TA, cât şi cu o componentă care poate fi atribuită variabilităţii TA.

În ceea ce priveşte parametrul statistic cel mai fidel pentru exprimarea variabilităţii TA în raport cu afectarea subclinică de organe exprimată ca IMT, am constatat că variabilitatea TA exprimată prin DS produce asociaţii puternice cu leziunea de organ ţintă indiferent de TA medie. În studiul de faţă, AVR nu este superioară DS în predicţia leziunilor de organe ţintă.

Cea mai importantă constatare a prezentului studiu este că, la pacienţii hipertensivi niciodată trataţi, variabilitatea TAs pe termen scurt, măsurată prin MATA şi cuantificată prin indici tradiţionali (DS), a fost asociată în mod semnificativ cu prezenţa leziunilor de organe ţintă. Rezultatele noastre confirmă lucrările anterioare, care evidenţiază că variabilitatea TA pare a fi un predictor al evenimentelor $\mathrm{CV}$, şi extinde în continuare aceste constatări, indicând faptul că variabilitatea TA, în special variabilitatea TAs, se manifestă ca un proces proaterosclerotic. Această analiză sugerează că menţinerea stabilităţii TA poate fi importantă pentru încetinirea progresiei complicaţiilor HTA.

Conflict of interest: none declared Financial support: none declared

9. Su TC, Lee YT, Chou S et al. Twenty-four-hour ambulatory blood pressure and duration of hypertension as major determinants for intima-media thickness and atherosclerosis of carotid arteries. Atherosclerosis 2006;184:151-156.

10. García-García A, García-Ortiz L, Recio-Rodriguez JI et al. Relationship of 24-h blood pressure variability with vascular structure and function in hypertensive patients. Blood Pressure Monitoring 2013; 18:101-106.

11. Mancia G, Parati G, Hennig M et al. Relation between blood pressure variability and carotid artery damage in hypertension: Baseline data from the European Lacidipine Study on Atherosclerosis (ELSA). J Hypertens. 2001;19:1981-1989.

12. Parati G, Ochoa JE, Salvi $P$ et al. Prognostic value of blood pressure variability and average blood pressure levels in patients with hypertension and diabetes. Diabetes Care. 2013;36:312-324.

13. Mena L, Pintos S, Queipo NV et al. A reliable index for the prognostic significance of blood pressure variability. J Hypertens. 2005; 23:505-511.

14. Stolarz-Skrzypek K, Thijs L, Richart T et al. Blood pressure variability in relation to outcome in the international database of ambulatory blood pressure in relation to cardiovascular outcome. Hypertension Research 2010;33:757-766.

15. Hansen TW, Thijs L, Li Y et al. Prognostic value of reading-to-reading blood pressure variability over 24 hours in 8,938 subjects from 11 populations. Hypertension 2010;55:1049-1057. 